\title{
Sterilization of Cosmopolites sordidus (Germar, 1834) (Coleoptera: Curculionidae) Eggs with Physiologic Insecticides as Integrated Pest Management Strategy
}

\author{
Nakano 0, Barros LS* and Morandi V \\ Department of Entomology and Acarology, "Luiz de Queiroz" College of Agriculture, \\ University of São Paulo, Brazil
}

*Corresponding author: Lucas Silva Barros, Department of Entomology and Acarology, "Luiz de Queiroz” College of Agriculture, University of São Paulo, Brazil, Email: lucasbarros.lsb@usp.br

\section{Research Article \\ Volume 3 Issue 8}

Received Date: September 05, 2018

Published Date: September 20, 2018

\begin{abstract}
In the world, Cosmopolites sordidus is a major pest in banana orchards. For its control, several management strategies have been used. However, it is important to add other control strategies to the integrated management of this pest. In this sense, this study evaluated the sterilant effect of some physiologic insecticides to $C$. sordidus. In order to accomplish this, a completely randomized experimental design was conducted under laboratory conditions. Five treatments (insecticides) and four repetitions (insects) were used for this proposed. The insecticides and concentrations were: abamectin at 1.5 and $3.0 \mathrm{ml} \mathrm{L}^{-1}$; lufenuron at 0.5 and $1.0 \mathrm{ml} \mathrm{L}^{-1}$ and water (check). Forty-eight fertilized females (12 insects $\mathrm{x} 4$ repetitions) were used per treatment. Banana pseudo stem baits were immersed in 1 liter of the solution for 10 minutes and after offered for $C$. Sordidus female adults. One week after treatment of the insects, they were transferred to untreated baits for evaluation. Number of $C$. sordidus eggs, fertilized eggs and egg feasibility was subjected to statistical analysis. The insecticide sterilant efficacy was calculated according to Henderson and Tilton formula. Both doses of lufenuron have satisfactory efficient sterilant effects on $C$. sordisus eggs, showing sterilant effects between 87.93 and $90.48 \%$. Unlike this, abamectin all concentrations did not showed same results. C. sordidus can be efficiently controlled with both lufenuron concentrations when infused on baits prepared using the banana tree own pseudo stem and it proves to be a good strategy to corm weevil management.
\end{abstract}

Keywords: Banana Rhizome Weevil; Insect Growth Regulators; Chemosterilants; Fruit Crops

\section{Introduction}

The corm weevil Cosmopolites sordidus (Germar) (Coleoptera: Curculionidae) is a major banana insect pest
(Musa spp.). This pest's larvae damages the corm and roots. Consequently, the emergence of new roots has delayed, and the nutrient uptake reduced. Weevil attack can prevent crop formation, cause significant yield 


\section{Open Access Journal of Agricultural Research}

reductions in ratooning cycles and contribute to a shortened plant life [1-3].

In addition, the yellowing of the leaves and the reduction of the size and weight of banana clusters has observed after the pest attack. Along with this, pathogenic microorganisms such as Fusarium oxysporum $f$. cubense responsible for the disease known as Panama disease, reach and install themselves through the galleries opened by $C$. sordidus $[4,5]$.

In traditional growing areas of central Uganda, western Tanzania and Costa Rica the weevil has been blamed as the primary factor contributing to the decline and disappearance of the highland cooking banana (Musa spp., genome group AAA-EA) [1,2,4].

Corm weevil damage and yields losses tend to increase with time, achieving losses up to $100 \%$ in cases of severe infestation [3]. It is estimated to occur an average $30 \%$ reduction in production due to its attack in Brazil [5].

Main contributing factors are the pest's biology and behavior. The pest adults can live for more than one year and lay about 100 eggs in the banana tree rhizome tissue $[1,6]$. In Brazil, the breaking out period for adults is between march and may and the adults can found throughout the entire year [7].

Currently in the world, many integrated pest management exist (IPM) to maintain the banana corm weevil populations at low levels, like a planting material free of egg, crop sanitation through destruction $C$. sordidus residues, trapping to monitoring and control, host plant resistance, biological control and chemical control $[8,9]$.

In spite this, an interesting IPM strategy is the pseudostem with lethal compounds to trap adult weevils it has aroused the interest of several researchers $[1,10]$. In this context, Aby, et al. research on entomopathogenic fungus Metarhizium and Beauveria bassiana with pseudo stem traps to control adults [3].

However, the best results of entomopathogenic fungus are on the adult phase of insect, penetrating through its integument [11]. Therefore, it would be interesting to use products that inhibit the pest at the egg stage, once the damage caused by the larvae.

In this sense, physiological insecticides or insect growth regulator (IGR) were also an option to control this pest because these compounds sterilizing activity on insect pest. According Schroeder, et al. Nakano, et al. Grosscurt and Avila and Nakano, physiological insecticides have greater stability and could have a longer sterilizing activity and sterilization is still the only effective way to eradicate pests on short notice [12-15].

Based on banana corm weevil's behavior and the sterilization characteristic of some physiological insecticides, lay forward the possibility of controlling this pest on banana orchards by using baits, taking into consideration that this pest does not scatter but is transported with the seedlings.

For this, the hypothesis based on C. sordidus female ingest bait containing physiological insecticide and hatching of the subsequently laid eggs will be prevent.

\section{Objective}

This research evaluated the sterilization effect of some physiologic insecticides on $C$. sordidus eggs and if this strategy could be considered an interesting control method of this pest on banana orchards.

\section{Material and Methods}

The trial took place between February and May 2016 at the Department of Entomology and Acarology Laboratory of Sao Paulo State University, Luiz de Queiroz College of Agriculture, Piracicaba, São Paulo.

\section{Insects}

In order to carry out the bioassay, baits were placed in the field for 10 days to get female $C$. sordidus. Adults of unknown ages were collected every day with pseudostem baits at the orchard of nanica banana. For 7 days collected adults females were distributed after obtaining a necessary quantity of them.

\section{Insecticides}

To test sterilization effect in C. sordidus, two commercial formulations of physiological insecticides were evaluated. Two concentrations of lufenuron (Match 50 EC, Syngenta Crop Protection, Sao Paulo, Brazil) and abamectin (Vertimec 18 EC, Syngenta Crop Protection, Sao Paulo, Brazil) were tested (Table 1). All commercial products were diluted in 1 liter of water. 


\section{Open Access Journal of Agricultural Research}

Table 1: Insecticides used in bioassay to evaluated Cosmopolites sordidus sterilization effect.

\begin{tabular}{|c|c|c|c|c|}
\hline \multirow{2}{*}{ Insecticide, Formulation ${ }^{1,2}$} & \multirow{2}{*}{ Commercial product (c.p) } & \multirow{2}{*}{ Chemical group } & \multicolumn{2}{|c|}{ Rate } \\
\hline & & & $\mathrm{ml} \mathrm{L}^{-1}$ c.p & g a.i $L^{-1}$ c.p \\
\hline \multirow{2}{*}{ Abamectin, $18 \mathrm{~g} \mathrm{~L}^{-1} \mathrm{EC}$} & \multirow{2}{*}{ Vertimec $18 ®$} & \multirow{2}{*}{ Avermectin } & 1.5 & 0.027 \\
\hline & & & 3 & 0.054 \\
\hline \multirow{2}{*}{ Lufenuron, $50 \mathrm{~g} \mathrm{~L}^{-1} \mathrm{EC}$} & \multirow{2}{*}{ Match 50® } & \multirow{2}{*}{ Benzoylphenylureas } & 0.5 & 0.025 \\
\hline & & & 1 & 0.05 \\
\hline
\end{tabular}

${ }^{1} \mathrm{EC}$ : emulsionable concentration; ${ }^{2}$ grams of active ingredient per liter of commercial product ( $\mathrm{g} \mathrm{i}^{\mathrm{a} \mathrm{L}^{-1}}$ ).

\section{Bioassay}

The bioassay was carried out using a completely randomized design with five treatments and four repetitions. Water was used with check of all of bioassay.

Baits consisted of banana pseudostem $(15 \mathrm{~cm} \times 10 \mathrm{~cm})$ for replication. These were immersed for 10 minutes in 1 liter of treatment solution. We used a vessel $20 \mathrm{~cm}$ in diameter and $15 \mathrm{~cm}$ in height, placing small holes in the cotton to control the moisture inside the vessel.

The insects remained in the vessels at the laboratory during the entire observation period. The evaluation began after two weeks, since direct contact of the eggs with the treated pseudostem could change the results. One week after insect contact with contaminated baits, these were replaced with non-treated baits and replaced again each week, and $C$. sordidus eggs were removed.

The eggs were collected during seventy days. After collected, the eggs were disinfected with bleach water at $0.5 \%$ and then incubated on Petri dishes, lined with absorbent paper, covered with PVC film and left in the environment. After this, the eggs were laid on the pseudostem surface for each treatment.

Larvae eclosion counting began one week after egg incubation, according to the number of larvae found in each dish. Evaluations were carried out up to the ninth week after commencement of the bioassay.

\section{Efficacy of Insecticide Sterilizing}

The efficacy of the sterilizing effect on $C$. sordidus eggs was calculated according to the formula of Henderson and Tilton, where [16]:

$\% \mathrm{E}=100 \mathrm{x}$ [1- (NIV in check before exposure $\mathrm{x}$ NIV in treatment after exposure/ NIV in control after exposure $\mathrm{x}$ NIV in treatment before exposure)],

where NIV = number of live insects.

\section{Data Analyses}

Data on the number of Cosmopolites sordidus eggs, the number of fertilized eggs and egg viability were subjected to analysis of variance (ANOVA) using the SISVAR 5.6 software and the means were compared by the Tukey's test $(\mathrm{p}<0,05)$.

\section{Results}

Results of total eggs demonstrated that there was no significant difference between treatments $(P=0.3122$; $F=1.306)$. In contrast, fertilized eggs $(P=0.0001$; $F=57.723)$ and feasibility of eggs $(P=0.0001 ; F=70.963)$ had statistically significant differences (Tables 2 and 3 ).

This result confirms the insecticides sterilizing effect efficacy, where avermectin 1.5 and $3.0 \mathrm{ml}$ demonstrated 35.09 and $47.92 \%$ respectively. On the other hand, the efficacy rate of lufenuron 0.5 and $1.0 \mathrm{ml}$ was 87.93 and $90.48 \%$ respectively (Table 3 ).

Table 2: Total and fertilized Cosmopolites sordidus eggs. Piracicaba 2016.

\begin{tabular}{|c|c|c|}
\hline Treatments $^{\mathbf{1}}$ & Total eggs $^{\mathbf{2 , 4}}$ & Fertilized eggs $^{\mathbf{3 , 4}}$ \\
\hline Avermectin $1.5 \mathrm{ml}$ & $14.25 \pm 0.85 \mathrm{a}$ & $9.25 \pm 0.75 \mathrm{~b}$ \\
\hline Avermectin $3.0 \mathrm{ml}$ & $12.00 \pm 1.22 \mathrm{a}$ & $6.25 \pm 0.47 \mathrm{c}$ \\
\hline Lufenuron $0.5 \mathrm{ml}$ & $14.50 \pm 1.55 \mathrm{a}$ & $1.75 \pm 0.47 \mathrm{~d}$ \\
\hline Lufenuron $1.0 \mathrm{ml}$ & $15.75 \pm 1.10 \mathrm{a}$ & $1.50 \pm 0.28 \mathrm{~d}$ \\
\hline Check & $13.75 \pm 1.10 \mathrm{a}$ & $13.75 \pm 2.21 \mathrm{a}$ \\
\hline$P$ & 0.3122 & 0.0001 \\
\hline$d$ f model & 4 & 4 \\
\hline$d$ f residue & 15 & 15 \\
\hline$F$ & 1.306 & 57.723 \\
\hline CV $(\%)$ & 16.97 & 21.02 \\
\hline
\end{tabular}

${ }^{1}$ Rate of commercial product per liter; ${ }^{2}$ Total eggs collected during seventy days; ${ }^{3}$ Fertilized eggs after $C$. sordidus adults exposure to pseudo stem baits contaminated with physiological insecticides; ${ }^{4}$ Numbers followed by the same letter do not differ statistically in column at the $5 \%$ probability level according to the Tukey's test. 


\section{Open Access Journal of Agricultural Research}

Table 3: Cosmopolites sordidus eggs feasibility and efficacy of insecticides sterilant effect. Piracicaba 2016.

\begin{tabular}{|c|c|c|}
\hline Treatments $^{\mathbf{1}}$ & Feasibility $^{\mathbf{2 , 4}}$ & Sterilant effect $^{\mathbf{3 , 4}}$ \\
\hline Avermectin $1.5 \mathrm{ml}$ & $68.25 \mathrm{~b}$ & 35.09 \\
\hline Avermectin $3.0 \mathrm{ml}$ & $47.19 \mathrm{c}$ & 47.92 \\
\hline Lufenuron $0.5 \mathrm{ml}$ & $12.32 \mathrm{~d}$ & 87.93 \\
\hline Lufenuron $1.0 \mathrm{ml}$ & $11.01 \mathrm{~d}$ & 90.48 \\
\hline Check & $100.00 \mathrm{a}$ & - \\
\hline$P$ & 0.0001 & - \\
\hline dfmodel & 4 & - \\
\hline$d$ fresidue & 15 & - \\
\hline$F$ & 70.963 & - \\
\hline CV (\%) & 18.86 & - \\
\hline
\end{tabular}

${ }^{1}$ Rate of commercial product per liter; ${ }^{2}$ Percentage of feasible eggs after $C$. sordius adults exposure to pseudo stem baits contaminated with physiological insecticides; ${ }^{3}$ Insecticide sterilant effect (\%E) calculated according to the Henderson and Tilton efficacy formula (1955); ${ }^{4}$ Numbers followed by the same letter do not differ statistically in column at the $5 \%$ probability level according to the Tukey's test.

\section{Discussion}

C. sordidus is the most important insect pest in banana orchard. To management of this pest, it is necessary understand your biology cycle and behavior in the field to chose the best IPM tool. Thus, several studies have shown pseudo banana bait capacity for capturing insect pest adults and use this trap with pesticides to control as a good strategy in banana IPM programs [3,13,17-23].

According to our study, statistical analysis of data shows that lufenuron in all concentrations was efficient to control banana corn weevil when compared to other treatments. Lufenuron was highly efficient for the control of banana beetles by sterilizing adults during the entire 70days period.

The efficiency of all lufenuron concentrations was between 87.93 and $90.48 \%$, which was considered satisfactory, given that the samples collected from the field were post-contaminated, even though the effect was present and the eclosion was impracticable.

Silva obtained similar results with other benzoylphenyl ureas insecticide. In this case, when baits had diflubenzuron at $0.25 \%$ as the active ingredient and the number of laid eggs was higher than the control but had no eclosion, showing the sterilizing effect [19].
Physiological insecticides or insect growth regulators (IGR), group such as lufenuron, have shown to have transovarian activity for Grapholita molesta, Plutella xylostella, Ceratitis capitata and Delia antiqua [24-27]. This insecticide group exerts its action by inhibiting the production of chitin, a major component of the insect exoskeleton.

In this sense, it is possible that effect over the spermatogenesis or oogenesis in insect occurred, although study shows that the effect of lufenuron on Diabrotica speciosa females wasn't necessarily sterilizing [28].

According this authors, this means that the product did not cause sterilization when observing unborn embryos formation, as possibly the females were fed the product, which was transferred to the embryos through the ovary, precluding larvae eclosion.

Silva developed anatomic ovary studies of $C$. sordidus and did not notice any apparent abnormality on the structure and formation of ovules on diflubenzuron tests [19]. Although larvae viability was low even for the control, the results obtained in this bioassay with lufenuron allow for some confidence with the data shown by Silva where lufenuron would be affecting directly the embryo formation in the eggs inside the ovaries [19].

The drastic effect would be occurring because the beetle goes for the inner tissue of baits, causing contamination by ingestion and by contact, different from Avila and Nakano that poisoned only through ingested feed, having no effect on contact. Even more the usage concentration here was $0.50 \%$ while Avila and Nakano used $0.033 \%$ doses.

A number of laid eggs on the lufenuron treatment compared to the control would indicate poisoning that usually accelerates weakening of organism. Silva also relates that thanks to Beauveria bassiana, a natural parasitism occurs in the populations of banana corm weevil in the field [19].

In contrast to lufenuron, avermectin in all the concentrations used, was not efficient and did not have great sterilization effect. Avermectin in all concentrations was between 35.09 and 47.92\%, which was not considered satisfactory to control this pest.

This insecticide had not much of an effect on the reproduction process but appeared to be promising at high concentrations. Silva studied the abamectin effect on 


\section{Open Access Journal of Agricultural Research}

the same pest and found that at doses of $2.8 \mathrm{ml}$ with $1.8 \%$ or $0.05 \%$ of active ingredient, showed eclosion inhibition [19].

Unlike lufenuron's mode of action, abamectin activate the GABA-gated chloride channel through a GABA-agonist type action in nervous system. In this case, activation of the channel suppresses neuronal activity, resulting in ataxia, paralysis and death of insects characterizing knock down insecticide and not "physiological" compounds $[29,30]$.

Other hypothesis is that abamectin have is quickly photo-degraded and the insecticidal effect has been lost faster [31,32]. For this, to abamectin exert toxicity in $C$. sordidus eggs in field, it is necessary put the baits in place with sun brightness to avoid this possible effect.

Although in our study did not demonstrate abamectin good sterelizing effect on C. sordidus eggs, there is differences when comparing both concentrations. In this sense, it is possible increased the sterilization effect with higher doses. However, studies to evaluate efficacy and economic feasibility will be necessary.

In general, this work be many advantages although further work have to be conducted to test lufenuron pseudo stem baits $C$. sordidus eggs sterilization efficiency in the field, for example: lufenuron acted as specific hormones on arthropods, and this is more safe for natural enemies and mammals; lufenuron in low concentrations showed efficient in C. sordidus control and when used in baits could avoid application of pesticides in large scale and reduce environmental impact; lufenuron could kill larvae in your damage phase before, which is interesting in crop protection $[33,34]$.

\section{Conclusion}

The physiological insecticide lufenuron at 0.5 and $1.0 \mathrm{ml} \mathrm{L}^{-1}$ concentrations showed sterilant effect on $C$. sordidus eggs, and this control method can be considered a good strategy to management this pest on banana orchards.

\section{References}

1. Gold CS, Pena JE, Karamura EB (2001) Biology and integrated pest management for the banana weevil Cosmopolites sordidus (Germar)(Coleoptera: Curculionidae). Integrated Pest Management Reviews 6(2): 79-155.
2. Polidoro BA, Dahlquist RM, Castillo LE, Morra MJ, Somarriba E, et al. (2008) Pesticide application practices, pest knowledge, and cost-benefits of plantain production in the Bribri-Cabécar Indigenous Territories, Costa Rica. Environmental Research 108(1): 98-106.

3. Aby $N$, Badou J, Traoré $S$, Kobénan $K$, Kéhé $M$, et al. (2015) Inoculated traps, an innovative and sustainable method to control banana weevil Cosmopolites sordidus in banana and plantain fields. Adv Crop Sci Technol 3(5): 1-5.

4. Rukazambuga NDTM, Gold CS, Gowen SR (1998) Yield loss in East African highland banana (Musa spp., AAAEA group) caused by the banana weevil, Cosmopolites sordidus Germar. Crop Prot 17(7): 581-587.

5. Batista Filho A, Takada HM, Carvalho AG (2002) Brocas da bananeira. In: Reunião Itinerante de Fitossanidade do Instituto Biológico-Banana, Anais São Paulo: Instituto Biológico, pp: 1-16.

6. Woodruff RE, Fasulo TR (1998) Banana Root Borer, Cosmopolites sordidus (Germar) (Insecta: Coleoptera: Curculionidae).

7. Batista Filho A, Sato ME, Raga A, Leite LG, Prada A (1991) A Flutuação populacional da broca da bananeira (Cosmopolites sordidus- Germar) Em Miracatu-SP, Ecosistema 16: 46-53.

8. Mesquita ALM (2003) Importância e métodos de controle do" moleque" ou broca-do-rizoma-dabananeira. Embrapa Agroindústria Tropical-Circular Técnica (INFOTECA-E) pp: 1-5.

9. Fancelli M, Milanez JM, Mesquita ALM, da Costa ACF, Costa JNM, et al. (2015) Artrópodes: pragas da bananeira e controle. Embrapa Agroindústria Tropical-Artigo em periódico indexado (ALICE).

10. Akello J, Dubois T, Coyne D, Kyamanywa S (2008) Endophytic Beauveria bassiana in banana (Musa spp.) reduces banana weevil (Cosmopolites sordidus) fitness and damage. Crop protection 27(11): 1437-1441.

11. Fancelli M, Dias AB, Delalibera I, de Jesus SC, do Nascimento AS, et al. (2013) Beauveria bassiana strains for biological control of Cosmopolites sordidus (Germ.)(Coleoptera: Curculionidae) in plantain. BioMed research international 2013: 1-7. 


\section{Open Access Journal of Agricultural Research}

12. Schroeder WJ, Beavers RA, Sutton RA, Selhima AG (1976) Ovicidal effect of Thompson-Hayward TH 6040 in Diaprepes abbreviatus on citrus in Florida. J Econ Entomol 69(6): 780-782.

13. Nakano O, Silveira Neto S, Batista GC, Yokoyama M, Degaspari ND, et al. (1977) Manual de InseticidasDicionario. SAO PAULO: AGRONOMICA CERES pp: 272.

14. Grosscurt AC (1978) Diflubenzuron: Some aspects of its ovicidal and larvicidal mode of action and evaluation of its practical possibilities. Pest Sci 9: 373-386.

15. Gallo D, Nakano O, Silveira Neto $S$, Carvalho RL, Batista GD, et al. (1988). Manual de entomologia agrícola. São Paulo: Agronômica Ceres pp: 649.

16. Henderson CF, Tilton EW (1955) Tests with acaricides against the brow wheat mite. J Econ Entomol 48: 157-161.

17. Martinez JA (1971) Flutuações da população da broca da bananeira (Cosmopolites sordidus-Germar). In: Anais da Sociedade Brasileira de Futicultura, Campinas pp: 187-194.

18. Mello RH, Mello ER, Martinez JA (1979) Eficiência de iscas envenenadas. Sobre a broca da bananeira ou moleque (Cosmopolites sordidus Germ.) In: Congresso Brasileirode Fruticultura, Pelotas. Anais 55.

19. Silva CG (1985) Estudos do comportamento da broca da bananeira Cosmopolites sordidus (Germar, 1824) (Coleoptera, Curculionidae), visando ao seu controle. Piracicaba: ESALQ-USP, pp: 82.

20. Alpizar D, Fallas M, Oehlschlager AC, Gonzalez LM (2000) Management of Cosmopolites sordidus and Metamasius hemipterus in banana by pheromonebased mass trapping. J Chem Ecol 38(3): 245-252.

21. González JM (2000) Efficacy of traps for the control and population dynamic studies of Cosmopolites sordidus. Manejo Integrado de Plagas 57: 45-48.

22. Queiroz JS, Fancelli M, Coelho Filho MA, da Silva Ledo CA, Sanches CG (2017) New type of trap for monitoring banana weevil population. African Journal of Agricultural Research 12(10): 764-770.

23. Corassa JN, Santos IB, Ferreira FTR, Pitta RM (2018) Baits for monitoring weevils in banana plantation of variety cv. Nanicão. Scientific Electronic Archives 11(1): 29-34.

24. Arnaldo BNO, Botton SM, Silveira GM, Silva A (2011) Efeito de inseticidas reguladores de crescimento sobre ovos, lagartas e adultos de Grapholita molesta (Busck) (Lep.: Tortricidae). Revista Brasileira de Fruticultura 33(2): 420-428.

25. De Bortoli SA, Thuler RT, Lopes BS (2008) Efeito de lufenuron e azadiractina sobre adultos de Plutella xylostella (Lepidoptera: Plutellidae). Científica 34(1): 53-58.

26. Navarro-Llopis V, Sanchis-Cabanes J, Ayala I, CasañaGiner V, Primo-Yüfera E (2004) Efficacy of lufenuron as chemosterilant against Ceratitis capitata in field trials. Pest management science 60(9): 914-920.

27. Zhou F, Zhu G, Zhao H, Wang Z, Xue M, et al. (2016) Sterilization effects of adult-targeted baits containing insect growth regulators on Delia antiqua. Scientific Reports 6: 32855.

28. Ávila CJ, Nakano 0, Chagas MCM (1998) Efeito do regulador de crescimento de insetos lufenuron na fecundidade e viabilidade de ovos de Diabrotica speciosa (Germar, 1824) (Coleoptera: Chrysomelidae). Revista de Agricultura (Piracicaba) 73(1): 69-78.

29. Bloomquist JR (1993) Toxicology, mode of action and target site-mediated resistance to insecticides acting on chloride channels. Comparative Biochemistry and Physiology 106(2): 301-314.

30. Campbell WC (2012) Ivermectin and abamectin. Springer Science \& Business Media.

31. Matos TAF, Dias ALN, Reis ADP, da Silva MRA, Kondo MM (2012) Degradation of abamectin using the photo-fenton process. International Journal of Chemical Engineering 2012: 1-7.

32. Awasthi A, Razzak M, Al-Kassas R, Harvey J, Garg S (2013) Evaluation of degradation kinetics for abamectin in formulations using a stability indicating method. Acta Pharmaceutica 63(1): 59-69.

33. Fonseca JP (1961) Consulta do Instituto Biológico. O Biológico 27: 218-219. 


\section{Open Access Journal of Agricultural Research}

34. Matos J, Simão SR (1967) A Broca da bananeira Cosmopolites sordidus Gernaim plantaçãodos

bananais. Revista da Agricultura 42: 15-17.

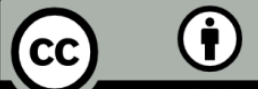

